\title{
SENTUHAN KASIH IBU, UPAYA STIMULASI TUMBUH KEMBANG ANAK DENGAN PIJAT BAYI PADA ANAK USIA 0-3 TAHUN DI DESA SELEBUNG KETANGGA, KECAMATAN KERUAK KABUPATEN LOMBOK TIMUR
}

\author{
Catur Esty Pamungkas ${ }^{1)}$, Aulia Amini ${ }^{1)}$, Cyntiya Rahmawati2) \\ 1)Program Studi D3 Kebidanan, Universitas Muhammadiyah Mataram \\ 2) Program Studi Farmasi, Universitas Muhammadiyah Mataram \\ Corresponding author : Catur Esty Pamungkas \\ E-mail : catur.esty@gmail.com
}

Diterima 15 Oktober 2020, Direvisi 26 Oktober 2020, Disetujui 27 Oktober 2020

\begin{abstract}
ABSTRAK
Bayi dapat tumbuh dan berkembang dengan baik jika kebutuhan dasarnya terpenuhi, yaitu asah, asih dan asuh. Kebutuhan asah adalah kebutuhan akan stimulasi dini. Pemberian stimulasi dini yang sesuai akan memungkinkan terbentuknya etika, kepribadian yang baik, kecerdasan, kemandirian, keterampilan dan produktivitas yang baik. Efektifitas pijat bayi memberikan manfaat pada perkembangan motorik sangat baik pada anak usia 8-28 hari dibandingkan dengan anak yang tidak diberikan stimulasi pijat bayi (Rizki, 2017). Melalui pemijatan peredaran darah akan lancar, Salah satu zat penting yang dibawa adalah oksigen. Terpenuhinya oksigen diotak secara cukup membuat konsentrasi dan kesiagaan bayi semakin baik (Sembiring, 2017). Solusi permasalahan yang ditawarkan yaitu "Sentuhan Kasih Ibu" Upaya Stimulasi Tumbuh Kembang anak dengan Pijat Bayi yang dilakukan Pada Anak Usia 0-3 Tahun di Desa Selebung Ketangga di Kecamatan Keruak Kabupaten Lombok Timur. Tujuan pengabdian ini memberikan informasi bagi masyarakat terutama orang tua mengenai manfaat setiap langkah dari pijat bayi. Tim PKMS akan memberikan pelatihan langsung kepada ibu yang akan dipraktikkan oleh narasumber yang berpengalaman, memiliki bidang ilmu yang sesuai dan telah mendapatkan pelatihan pijat bayi sebelumnya, sehingga setiap informasi diberikan oleh orang yang tepat. Setelah diberikan pelatihan pijat bayi tersebut, diharapkan ibu dapat mempraktikan sendiri pijat bayi di rumah.Jumlah responden yang mengikuti kegiatan ini sebanyak 32 balita. Hasil pengadian didapatkan terbanyak responden 12-24 sebanyak 19 balita $(59,4 \%)$. Hasil pre test didapatkan 23 responden memiliki pengetahuan kurang dan post test sebagian besar pengetahuan cukup sebanyak 18 responden. Hasil follow up kemampuan pijat bayi didapatkan 24 reponden mampu melakukan pijat bayi dengan benar.
\end{abstract}

Kata kunci: stimulasi tumbuh kembang; bayi; pijat bayi.

\begin{abstract}
Babies can grow and develop well if their basic needs, which are teasers, love and foster. The need for sharpening is the need for early stimulation. Providing first inspiration appropriate will enable the formation of ethics, a good personality, intelligence, independence, skills and good productivity. The effectiveness of baby massage provides benefits to motor development is very good in children aged 828 days compared with children who do not give stimulation of baby massage (Rizki, 2017). Through massage, the blood circulation will be smooth. One of them the essential substance carried is oxygen. Fulfilment of oxygen in the brain is sufficient to make the baby's concentration and alertness are getting better (Sembiring, 2017). The solution to the problem offered is the "Touch of Mother's Love" Efforts to Stimulate Child Development with Infant Massage which was carried out on children aged 0-3 years in Selebung Ketangga Village in Keruak District East Lombok Regency. The purpose of this service is to provide information for the community, especially parents, regarding the benefits of every step of baby massage. The Stimulus Community Service Team (PKMS) will provide training directly to the mother who will be practised by experienced speakers who have fields science according to the training and baby massage before, so every information given by the right person. After being given the baby massage training, it is hoped that the mother can practicing baby massage at home on their own. The number of respondents who participated in this activity was 32 toddler. The results obtained were the most respondents $12-24$ as many as 19 toddlers (59.4\%). Pre results test found 23 respondents have less knowledge and most of the post-test sufficient knowledge of 18 respondents. The follow-up results of the infant massage ability were obtained 24 respondents are able to massage the baby properly.
\end{abstract}

Keywords: growth and development stimulation; baby; baby massage. 


\section{PENDAHULUAN}

Bayi dapat tumbuh dan berkembang dengan baik jika kebutuhan dasarnya terpenuhi, yaitu asah, asih dan asuh. Kebutuhan asah adalah kebutuhan akan stimulasi dini. Pemberian stimulasi dini yang sesuai akan memungkinkan terbentuknya etika, kepribadian yang baik, kecerdasan, kemandirian, keterampilan dan produktivitas yang baik (Heath A and Bainbridge N, 2007). Melalui pemijatan peredaran darah akan lancar mengalir keseluruh tubuh, termasuk ke otaknya. Salah satu zat penting yang dibawa adalah oksigen. Terpenuhinya oksigen diotak secara cukup membuat konsentrasi dan kesiagaan bayi semakin baik (Sembiring, 2017). Di Indonesia pelaksanaan pijat bayi di masyarakat desa masih dipegang perannya oleh dukun bayi. Selama ini, pemijatan tidak hanya dilakukan pada saat bayi sehat, tetapi juga pada bayi rewel dan sudah menjadi rutinitas perawatan bayi setelah lahir (Aminarti, 2013).

Menurut hasil Pemantuan Gizi Nasional tahun 2018 di Indonesia sebanyak 13,8\% balita mempunyai status gizi kurang, $3,9 \%$ balita mempunyai status gizi buruk dan $19,3 \%$ balita mempunyai status gizi pendek (Riskesdas, 2018). Nusa Tenggara Barat hasil pemantauan gizi tahun 2018 didapatkan balita dengan status gizi kurang sebanyak $20,49 \%$, status gizi buruk $5,91 \%$ dan anak dengan status pendek sebanyak $33,49 \%$. Presentase tersebut melebihan rata-rata nasional. Lombok timur merupakan sampel terbanyak pada Riset Kesehatan Dasar Tahun 2018 pada usia 0-23 bulan sebanyak 484 (Riskesdas NTB, 2018).

Penelitian yang dilakukan (Irva, Hasanah, \& Woferst, 2014) pijat bayi memberikan manfaat meningkatkan berat badan sebesar 700 gram selama 2 minggu pemijatan. Pada bayi usia 0-3 tahun, gerakan yang dilakukan lebih mendekati usapan-usapan halus, tekanan ringan, dan dengan tekanan, disarankan pemijatan dilakukan sekitar 15 menit, sesuai usia bayi dan waktu dapat ditingkatkan sesuai kebutuhan (Roesli, 2016). Efektifitas pijat bayi memberikan manfaat pada perkembangan motorik sangat baik pada anak usia 8-28 hari dibandingkan dengan anak yang tidak diberikan stimulasi pijat bayi (Rizki, 2017).

Pijat bayi yang dilakukan sebelum tidur malam dapat meningkatkan lamanya tidur malam pada bayi usia 3 - 6 bulan (Permata, Fisioterapi, \& Abdurrab, 2017). Di sisi lain pijat juga dapat memperlancar peredaran darah dan meningkatkan metabolisme sel, dari rangkaian tersebut berat badan bayi akan meningkat (Subakti, $Y$ and Anggrani, 2008). Menurut penelitian yang dilakukan (Murtiningsih, Wijaya, \& Permadi, 2019) pijat bayi dapat meningkatkan motorik kasar duduk dan merangkak mandiri pada bayi usia 9 bulan. Banyak manfaat dari intervensi pijat bayi ini bisa diterapkan dari ibu ke anak dengan pelatihan pijat bayi secara berkelanjutan.

Stimulasi sentuh dapat merangsang semua sistem sensorik dan motorik yang berguna untuk pertumbuhan otak, membentuk kecerdasan emosi, inter, intrapersonal dan untuk merangsang kecerdasan-kecerdasan lain. Pijat bayi memberikan manfaat baik dalam hal biokimia maupun fisik yang positif seperti menurunkan hormone stress pada bayi, mengubah gelombang otak secara positif, memperlancar sirkulasi darah dan pernapasan, meningkatkan berat badan bayi, membuat rileks saat bayi tidur, menyembuhkan sakit kolik dan kembung, serta meningkatkan ikatan kasih sayang antara ibu dan bayi dan meningkatkan produksi ASI (Maharani, 2009).

Seorang anak membutuhkan dukungan untuk mencapai pertumbuhan dan perkembangan sesuai usianya, melalui program 1000 Hari Pertama Kehidupan pemantuan tumbuh kembang dimulai sejak dalam kandungan, kecukupan nutrisi dan stimulasi yang mendukung pertumbuhan dan perkembangan sampai 2 tahun pertama kehidupan anak (Kementerian Koordinator Bidang Kesejahteraan Rakyat, 2013). Setiap anak perlu mendapat stimulasi rutin sedini mungkin dan terus menerus pada setiap kesempatan. Stimulasi tumbuh kembang anak dilakukan oleh ibu dan ayah yang merupakan orang terdekat dengan anak, pengganti ibu/pengasuh anak, anggota keluarga lain dan kelompok masyarakat di Lingkungan rumah tangga masing-masing dan dalam kehidupan sehari-hari. Kurangnya stimulasi dapat menyebabkan penyimpangan tumbuh kembang anak bahkan gangguan yang menetap (Depkes., 2016).

Pelatihan dan pendampingan pijat bayi kepada kader tentang pemahaman kader tentang pentingnya sentuhan dan pijat bayi bagi bayi yang telah dilakukan oleh (Kusuma, Agustina, \& Susanti, 2019), didapatkan Pelatihan pijat bayi memberikan peningkatan pengetahuan kader $(93,33 \%)$, dan pendampingan pijat bayi memberikan manfaat pada kader sehingga terampil melakukan pijat bayi $(92,31 \%)$. Sehingga sangat perlu dilakukan pelatihan stimulasi pijat bayi bagi orang terdekat anak yaitu ibu, dengan bounding yang sudah terbentuk akan sangat mudah memberikan pijatan pada anak. 
Langkah awal yang dilakukan oleh para ibu untuk memperkecil resiko ataupun komplikasi pijat bayi, hendaklah orang tua jeli dalam memilih praktisi pijat untuk bayinya. Apabila ibu belum mengerti tentang cara memijat bayi yang benar sebaiknya ibu mencari informasi melalui media yang membahas tentang pijat bayi yang benar serta diharapkan memberikan informasi pada ibu, selanjutnya ibu mengaplikasikan sendiri. $\mathrm{Di}$ Indonesia pelaksanaan pijat bayi di masyarakat desa masih dipegang perannya oleh dukun bayi. Selama ini, pemijatan tidak hanya dilakukan pada saat bayi sehat, tetapi juga pada bayi sakit atau rewel dan sudah menjadi rutinitas perawatan bayi setelah lahir (Aminarti, 2013).

$$
\text { Pemantuan Pertumbuhan dan }
$$

Perkembangan anak menjadi tolak ukur kesehatan anak di Indonesia, Nusa Tenggara barat memiliki status gizi kurang yang mengalami mengalami penambahan dari $20,2 \%$ di tahun 2016 menjadi $22,6 \%$ pada tahun 2017 sebanyak 15,5\% (Dinkes NTB, 2017). hasil kumpulan data nasional anak Indonesia masih banyak yang pertumbuhannya mengalami stunting (pendek). Dilihat dari data kejadian stunting di kabupaten Lombok timur, terjadi peningkatan kejadian stunting sebesar $34,6 \%$ pada tahun 2016 menjadi $35,1 \%$ pada tahun 2017 (Dinkes NTB, 2017). Kecamatan keruak yang ada di Lombok timur masuk dalam daftar desa prioritas Kawasan Perdesaan Prioritas Nasional (KPPN, 2019).

Kecamatan Keruak merupakan salah satu wilayah di Kabupaten Lombok Timur dengan luas wilayah $40,49 \mathrm{~km}^{2}$ dengan jumlah desa sebanyak 15 desa. Tingkat kepadatan penduduknya sudah mencapai 49,822 jiwa yang tersebar di 15 Desa yaitu Batu putik, dane rase, keruak, ketangga jeraeng, ketapang raya, medana raya, montong belae, pijot, pijot utara, pulau maringkik, selebung ketangga, senyiur, sepit, setungkep lingsar, tanjung luar. Memiliki 1 pusat kesehatan masyarakat yaitu Puskesmas Keruak (BPS Provinsi NTB, 2020). Hasil wawancara ke masyarakat di kecamatan keruak masalah kesehatan yang paling umum adalah masalah membuang sampah sembarangan. Khusus di Desa Selebung Ketangga, musim tembakau saat ini menyebabkan meningkatnya penyakit ISPA, hal ini sangat berbahaya bagi kesehatan anak. Penyakit ISPA yang berlangsung lama dapat menyebabkan masalah tumbuh kembang. Hasil wawancara dibeberapa ibu di Desa Selebung masih belum paham manfaat pijat bayi dan sampai sekarang masyarakat masih mempercayaan pijat bayi pada dukun bayi setempat. Berdasarkan latar belakang tersebut peneliti akan melakukan pengabdian masyarakat yaitu edukasi respoden dan pelatihan pijat bayi, sehingga dapat menstimulasi pertumbuhan dan perkembangan balita dengan maksimal.

\section{METODE}

Metode kegiatan PKMS ini melibatkan setiap kader yang ada di Desa Selebung Kecamatan Keruak Kabupaten Lombok Timur. PKMS ini mengadopsi langkah-langkah action research yang terdiri dari 4 (empat) tahapan, yaitu : perencanaan, tindakan, observasi dan evaluasi, dan refleksi (Yaumi, Muhammad dan Damopolii, 2014). Kegiatan masing-masing tahapan adalah sebagai berikut :

\section{Tahap Perencanaan}

Koordinasi dan pemberian informasi kegiatan PKMS kepada Tim pelaksana, mitra, dan perangkat desa. Tim pelaksana diundang untuk mengadakan pertemuan persiapan pelaksanaan dengan melibatkan mahasiswa $D$ III Kebidanan sebanyak 4 orang dan narasumber pelatih pijat bayi. Mahasiswa sebagai tim inti dibekali keterampilan pijat bayi yang langsung di praktikkan pada tanggal 15 Juni 2020 di laboratorium Kebidanan dan pembekalan mengenai informasi tentang tujuan pijat bayi, manfaat pijat bayi, hal-hal yang perlu diperhatikan dalam pijat bayi, langkah-langkah pijat bayi, dan membahas soal pretest dan posttest yang akan dibagikan pada peserta PKMS, agar mahasiswa mampu mendiskripsikan pengetahuan peserta PKMS tentang pijat bayi sebelum dan setelah kegiatan dilaksanakan. Pada pembekalan ini juga menjelaskan rangkaian kegiatan secara teknis pelaksanaan pengabdian. Rapat penyusunan materi pijat bayi dan video simulasi pijat bayi. Materi yang akan digunakan terkait stimulasi pijat bayi, materi yang disiapkan antara lain : Tujuan dan manfaat pijat bayi, Waktu Pemijatan, Tempat pemijatan bayi, Persiapan sebelum pemijatan, Hal-hal yang dianjurkan dan tidak dianjurkan selama pemijatan bayi, Cara pemijatan sesuai usia bayi, Langkah-langkah pemijatan bayi.

Sosialisasi kegiatan PKMS pada desa mitra, Sosialisasi dilakukan dalam bentuk koordinasi dengan mengundang kader posyandu. Kegiatan sosialisasi dilakukan oleh Tim Pelaksana dilaksanakan di rumah kader dusun selebung pada Tanggal 17 Juni 2020 . Dengan memperhatikan protokol kesehatan dengan selalu menggunakan masker dan menjaga jarak. Sosialisasi dilakukan mengingat pentingnya peran aktif kader dalam merekrut peserta dalam keikutsertaan pengabdian berdasarkan kriteria ibu dan balita dalam kondisi sehat, bersedia mengikuti kegiatan 
hingga akhir dan bertempat tinggal di wilayah Desa Selebung Ketangga. Kegiatan diikuti oleh sekitar 10 kader dan perwakilan peserta pengabdian yang bersedia mengikuti sosialisasi kegiatan PKMS.

Persiapan pelaksanaan pijat bayi. Pada Tangga 18 Juni 2020 tim melakukai survey lokasi tempat kegiatan PKMS yaitu Aula Desa Selebung Ketangga. Menyiapkan alat dan bahan yang dibutuhkan dalam pijat bayi seperti matras, oil massage, video tentang langkahlangkah pijat bayi.

\section{Tahapan Tindakan}

Kegiatan pelatihan pijat bayi dilaksanakan pada hari Minggu, 21 Juni 2020. Peserta melakukan registrasi pada saat kegiatan, dengan tetap menjaga protokol kesehatan selama pandemi covid 19 , setiap peserta diberikan masker, hand sanitizer dan menjaga jarak sama kegiatan berlangsung. Pada kegiatan PKMS ini peserta diberikan baby oil untuk digunakan selama pijat bayi.

Penyampaian materi tentang tujuan, manfaat dan langkah-langkah pijat bayi yang benar pada masyarakat terutama kader dan ibu yang memiliki anak usia 0-3 tahun.

Pelaksanaan edukasi mengenai pijat bayi dan pelatihan pijat bayi yang akan dipraktikan dengan metode demostrasi pada ibu-ibu yang memiliki anak usia 0-3 tahun oleh narasumber yang bernama Uyunun Nudhira, S.ST.,M.Kes yang akan dibantu oleh mahasiswa kebidanan.

\section{Tahapan Observasi dan Evaluasi}

Observasi dilakukan terhadap peningkatan pengetahuan pada ibu tentang manfaat, tujuan dan langkah-langkah pijat bayi setelah dilakukannya pemaparan materi dan demostrasi pijat bayi. Instrumen yang digunakan berupa kuesioner. Beberapa hal yang diobservasi adalah kendala-kendala dan masalah yang muncul dalam proses kegiatan pelatihan pijat bayi. Evaluasi dilakukan terhadap pengetahuan yang dihasilkan. Pre test telah dilaksanakan pada saat kegiatan pelatihan pijat bayi berlangsung, lama waktu berkumpul selama pandemik covid19 menjadi pertimbangan dalam pelaksanaan PKMS sehingga kegiatan post test dilaksanakan 1 minggu setelah kegiatan berlangsung yaitu pada tanggal 28 juni 2020. Kegiatan dilakukan dengan mendatangi rumah peserta satu persatu yang dilakukan oleh 4 mahasiswa.

\section{Tahapan Refleksi}

Memantau pelaksanaan pijat bayi yang dilakukan oleh beberapa ibu di rumah sebagai langkah follow up terhadap pelaksanaan pijat bayi. Tindak lanjut pijat bayi yang dilaksanakan di rumah masing-masing akan dilakukan 2 minggu setelah pelatihan dilakukan. Kegiatan masih berlangsung, dalam pelaksanaannya sudah $60 \%$ dari jumlah keseluruhan peserta yang mengikuti pelatihan pijat bayi telah kunjungan.

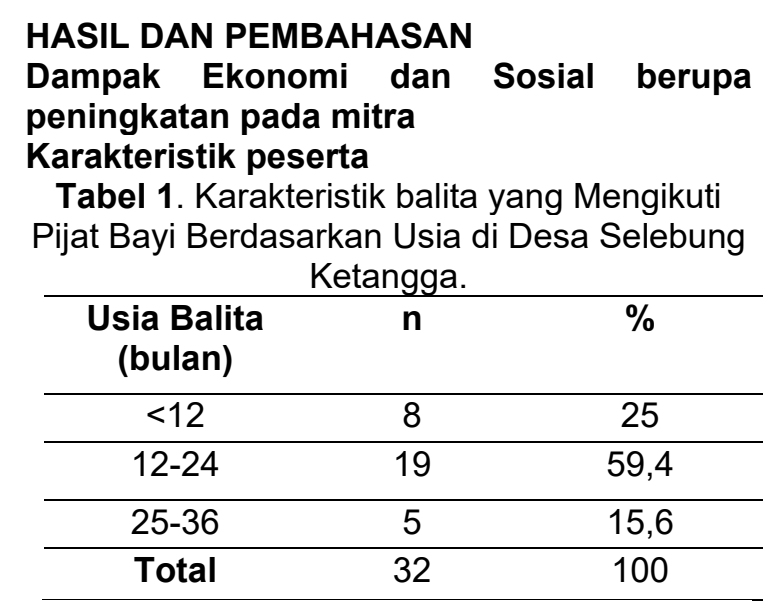

Berdasarkan tabel 1. Didapatkan hasil usia balita terbanyak mengikuti kegiatan stimulasi pertumbuhan dan perkembangan dengan pijat bayi sebanyak 19 peserta yaitu $59,4 \%$ pada usia 12-24 bulan, dan jumlah terendah yaitu pada usia 25-36 bulan sebanyak 5 peserta atau $15,6 \%$. Pada pelaksanaan pengabdian peserta usia kurang dari 6 bulan di eksklusi, mengingat usia balita yang masih sangat muda dan mudah tertular penyakit dan virus.

\section{Peningkatan pengetahuan}

Pada kegiatan pengabdian ini peserta diminta mengisi soal pengetahuan pijat bayi yang berisi 15 butir soal, didapatkan peningkatan pengetahuan peserta PKMS, dapat terlihat dari grafik berikut.

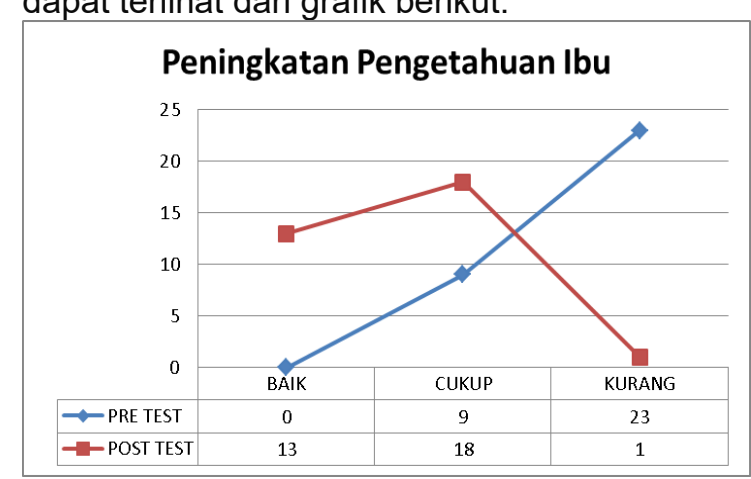

Gambar 1. Tingkat Pengetahuan lbu tentang Pijat Bayi

Berdasarkan Gambar 1. diatas didapatkan peningkatan pengetahuan peserta PKMS. Saat dilakukan pre test, diperoleh bahwa sebagian besar ibu memiliki pengetahuan yang kurang yaitu sebanyak 23 orang, dan setelah dilakukan pelatihan, kemudian tim memberikan post test, didapatkan hasil bahwa terdapat peningkatan 
pengetahuan ibu tentang stimulasi tumbuh kembang dengan pijat bayi.

\section{Perilaku ibu dalam melakukan pijat bayi secara mandiri}

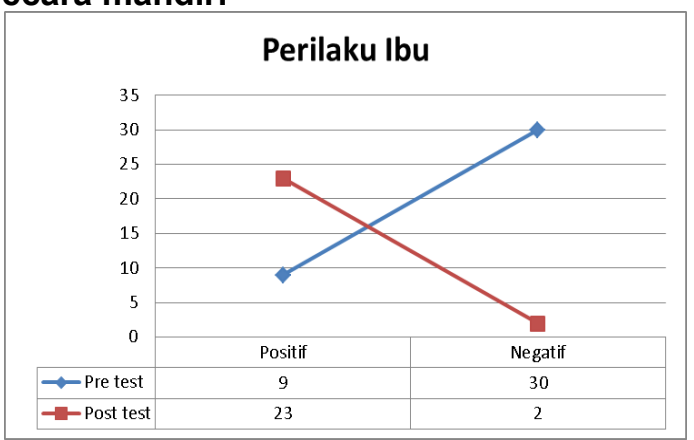

Gambar 2. Prilaku ibu dalam melakukan Pijat bayi

Pada kegiatan pengabdian ini, ibu diminta mengisi soal tentang prilaku pijat bayi sebanyak 10 soal yang dibagikan sebelum dilakukan pelatihan pijat bayi. Diperoleh hasil bahwa sebagian besar ibu yang memiliki bayi/balita dapat menerima dengan positif adanya pelatihan stimulasi tumbuh kembang dengan pijat bayi. Mereka mengatakan bahwa kegiatan ini sangat bermanfaat dan mudah dilakukan untuk dapat diterapkan langsung agar dapat menstimulasi tumbuh kembang bayi/balitanya.

\section{Kontribusi Mitra Terhadap Pelaksanaan}

Mitra dalam kegiatan pengabdian ini sangat kooperatif dan membatu pelaksanaan stimulasi pijat bayi dengan mulai melakukan persiapan dengan menyediakan sarana prasarana pelatihan seperti tempat pelatihan dan sound system yang digunakan untuk peserta pelatihan. Mitra memberikan kemudahan dalam mengumpulan informasi terkait jumlah ibu yang ada di wilayah Desa Selebung Ketangga, menunjuk beberapa kader sebagai pendamping selama proses pelaksanaan pengabdian masyarakat, menunjukkan lokasi pengabdian dilaksanakan dan mendukung kegiatan penyuluhan pada ibu serta mengharapkan kegiatan serupa bisa dilaksanaakan Kembali di wilayah Desa Selebung Ketangga. Kotribusi mitra selanjutnya, trainer (Dosen dan Mahasiswa) dan kader posyandu serta perangkat Desa terlibat dalam penyuluhan dan pelatihan pijat bayi, trainer dan kader posyandu serta perangkat desa terlibat dalam persiapan secara teknik seperti membantu persiapan tempat dan metode mengumpulkan ibu yang memiliki anak usia 0-3 tahun dalam satu waktu. Beberapa dokumentasi kegiatan pelaksanaan pengabdian masyarakat dapat dilihat dalam gambar di bawah ini.

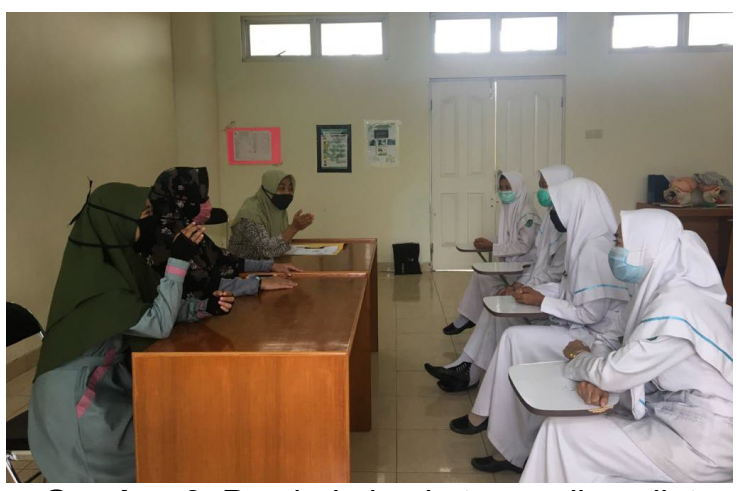

Gambar 3. Pembekalan keterampilan pijat bayi pada mahasiswa dalam persiapan pemantauan pijat bayi pada peserta PKMS.

Berdasarkan Gambar 3. Pada pembekalan ini Tim pengabdian melakukan sosialisasi pelaksanaan pijat bayi Pada Tanggal 16 Juni 2020 kepada mahasiswa sebanyak 4 orang sebagai tim pelaksana dan kepada kader serta apartur desa yang terlibat pada kegiatan pengabdian ini. Menginfokan pelatihan pijat bayi akan dilaksanakan pada balita usia kurang dari 3 tahun dan dilaksanakan di 3 dusun yang tersebar di kecamatan selebuh ketangga.

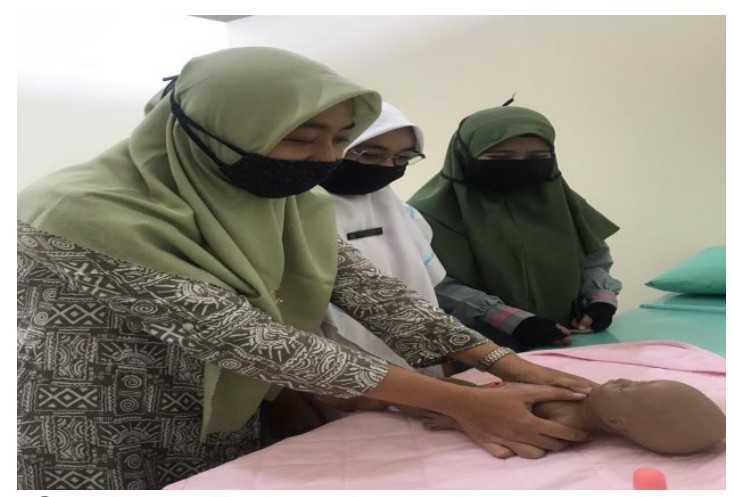

Gambar 4. Trainer pijat bayi mempraktikkan pijat bayi

Berdasarkan Gambar 4. Trainer mempraktikkan cara pijat bayi sesuai langkah yang benar. Langkah awal memastikan lokasi pemijatan dan kondisi anak sehat, kemudian menggunakan baby oil sebagai pelumas saat pemijatan, setelah itu dilakukan pemijatan dari kepala, muka, dada, perut hingga kaki secara berurutan kurang lebih 20 menit. 


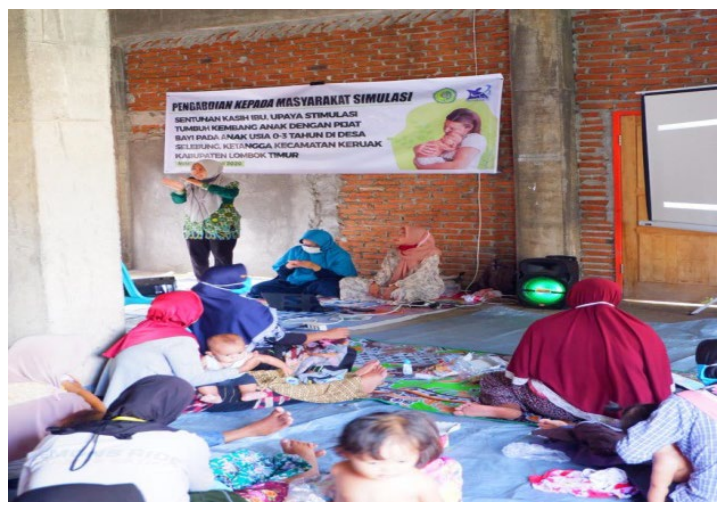

Gambar 5. Tim memaparkan materi tentang tujuan pijat bayi, manfaat pijat bayi, hal-hal yang perlu diperhatikan dalam pijat bayi, dan langkah-langkah pijat bayi

Berdasarkan Gambar 5. Tahap ini telah dilaksanakan pemaparan materi tentang pijat bayi pada tanggal 21 Juni 2020 kepada 32 ibu yang memiliki balita dan 4 kader yang hadir. Diawal kegiatan peserta telah melakukan absensi yang telah tersedia di meja registrasi dan mengisi form post test pengetahuan tentang pijat bayi. Pelaksanaan berlangsung tertib dengan selalu memperhatikan protokol kesehatan dengan membagikan masker dan handsanitizer.

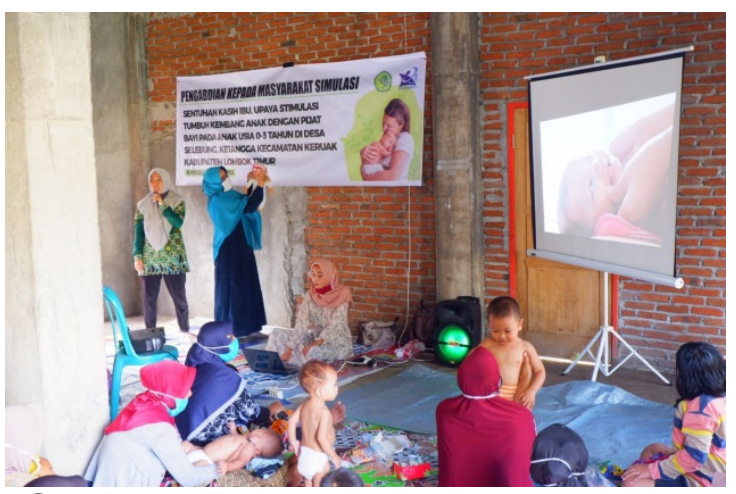

Gambar 6. Trainer pijat bayi mempraktikkan pijat bayi pada peserta

Berdasarkan Gambar 6. Trainer mempraktikkan langkah demi langkah pijat bayi yang benar. Tim pengabdian menyediakan baby oil sebagai oil yang direkomendasikan dalam pijat bayi dan digunakan peserta saat mempraktikkan pijat bayi langsung pada anaknya. Dipantau oleh tim pelaksanan, pelaksanaan pijat bayi berjalan lancar, sebanyak 32 balita mengikuti pijat bayi.

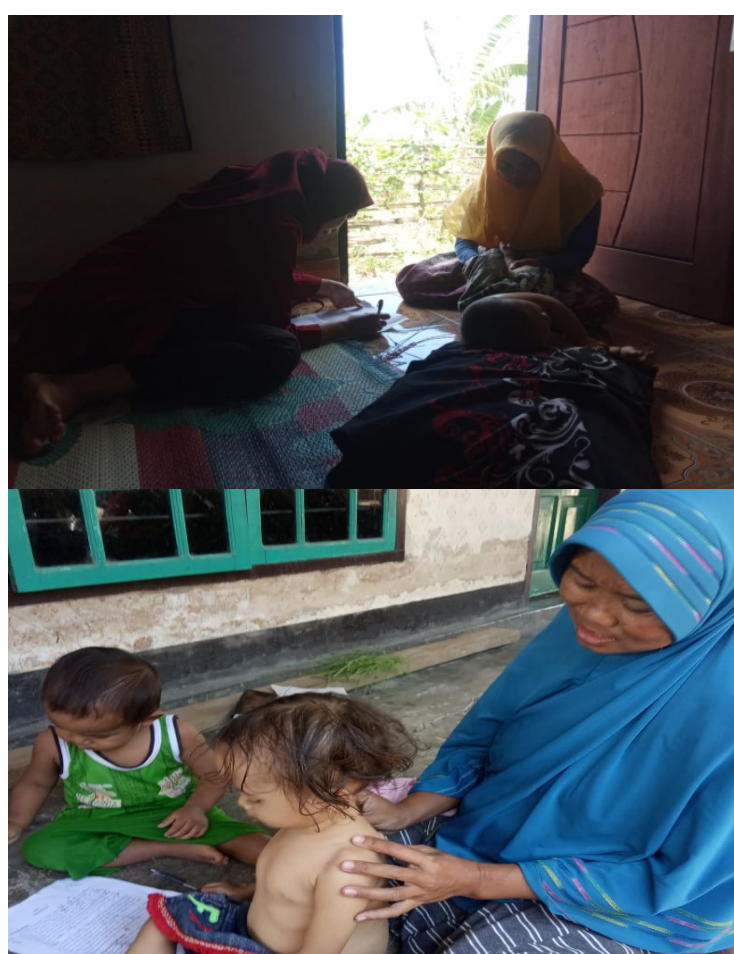

Gambar 7. Pemantuan pijat bayi mandiri di rumah

Berdasarkan Gambar 6. Tahap refleksi yang dilakukan responden secara mandiri melakukan pijat bayi pada balita di rumah masing-masing. Pemantuan ini telah dilakukan 2 minggu setelah kegiatan pelatihan pijat bayi, dari 32 responden, didapatkan 24 responden memiliki kemampuan pijat bayi yang benar. Pemantuan dilakukan oleh tim pengabdian menggunakan ceklist pijat bayi sesuai langkah benar.

\section{SIMPULAN DAN SARAN}

Tim PKMS sudah memberikan informasi dan edukasi tentang pijat bayi pada anak usia 0-3 tahun di Desa Selebung Ketangga di Kecamatan Keruak Kabupaten Lombok Timur Pada 32 responden. Tim PKM sudah memberikan pelatihan pijat bayi pada anak usia 0-3 tahun di Desa Selebung Ketangga di Kecamatan Keruak Kabupaten Lombok Timur. Tim PKMS sudah melakukan evaluasi kegiatan pijat bayi pada anak usia 0-3 tahun di Desa Selebung Ketangga di Kecamatan Keruak Kabupaten Lombok Timur.

Kegiatan pengabdian masyarakat seperti ini dapat dilakukan secara rutin baik di lokasi yang sama maupun di lokasi yang berbeda dengan sasaran masyarakat yang benar-benar membutuhkan pelayanan kesehatan terutama mengenai tumbuh kembang pada bayi/balita. 


\section{UCAPAN TERIMAKASIH}

Tim penulis mengucapkan terima kasih kepada Kementrian Riset dan Teknologi/Badan Riset dan Inovasi Nasional (Ristek-BRIN) yang telah mendanai kegiatan pengabdian ini sehingga terlaksana dengan baik. Lembaga Penelitian dan Pengabdian Masyarakat Universitas Muhammadiya dan Mitra Pengabdian Masyarakat yang telah mendukung dan memfasilitasi kegiatan pengabdian sehingga berjalan dengan lancar.

\section{DAFTAR RUJUKAN}

Aminarti, D. (2013) Pijat dan senam untuk bayi \& balita. Yogyakarta: Brilliant Books.

BPS Provinsi NTB (2020) Kabupaten Lombok Timur Dalam Angka. Mataram: BPS Provinsi NTB.

Depkes., R. (2016) 'Pedoman pelaksanaan stimulasi, deteksi, dan intervensi tumbuh kembang anak.'

Dinkes NTB (2017) Pemantauan Status Gizi Balita Provinsi NTB. Mataram: Dinkes Provinsi NTB.

Heath A and Bainbridge N (2007) Baby Massage: Kekuatan Menenangkan dari Sentuhan. Jakarta: Dian Rakyat.

Irva, T. S., Hasanah, O.- and Woferst, R.(2014) 'Pengaruh terapi pijat terhadap peningkatan Berat badan bayi', Jurnal Online Mahasiswa (JOM) Bidang IImu Keperawatan, 1(2), pp. 1-9. Available at:

https://jom.unri.ac.id/index.php/JOMPS IK/article/view/4142/4035.

Kementerian Koordinator Bidang Kesejahteraan Rakyat (2013) 'Kerangka Kebijakan Gerakan Nasional Percepatan Perbaikan Gizi dalam Rangka Seribu Hari Pertama Kehidupan (Gerakan 1000 HPK)', p. 71.

KPPN (2019) Daftar Desa Pada Kawasan Perdesaan Prioritas Nasional. Jakarta: Kementrian Desa.

Kusuma, R. M., Agustina, S. A. and Susanti, D. (2019) 'Pelatihan dan pendampingan pijat bayi pada kader POSYANDU sebagai stimulasi tumbuh kembang balita di Tegalrejo , KotaYogyakarta', 3(3), pp. 355-366.

Maharani, S. (2009) Pijat dan Senam Sehat Untuk Bayi. Yogyakarta: Kata Hati.

Murtiningsih, M., Wijaya, I. P. D. and Permadi, A. W. (2019) 'Pijat Bayi Untuk Meningkatkan Motorik Kasar Duduk Dan Merangkak Mandiri Pada Bayi Usia 9 Bulan Di Upt Kesmas Sukawati l', Jurnal Kesehatan Terpadu, 3(1), pp. 22-25. doi: 10.36002/jkt.v3i1.710.

Permata, A., Fisioterapi, P. S. D. and Abdurrab,
U. (2017) 'Pengaruh Pijat Bayi Terhadap Peningkatan Lama Tidur Malam Pada Bayi 3 - 6 Bulan Effects of Baby Massage to Improvement of Long Night Sleep on Baby 3-6 Months', (2), pp. 37-45.

Priyoto (2014) Teori Sikap dan Prilaku dalam Kesehatan. Yogyakarta: Nuha Medika.

Riskesdas NTB (2018) 'Hasil Riskesdas NTB 2018', pp. 1-100.

Riskesdas, R. (2018) 'Hasil Utama Riskesdas 2018 '.

Rizki, L. (2017) 'Efektivitas Pijat Bayi Pada Perkembangan Motorik pada Bayi Usia 8-28 hari', Maternal and Neonatal Health Journal, 1(2), pp. 76-80.

Roesli, U. (2016) Pedoman Pijat Bayi. Jakarta: Trubus Agriwidya.

Sembiring, J. B. 201. (2017) Asuhan Neonatus, Bayi, Balita, Anak Pra Sekolah. Yogyakarta: Deepublish.

Subakti, Y and Anggrani, D. (2008) Keajaiban Pijat Bayi dan Balita. Jakarta: Wahyu Media.

Yaumi, Muhammad dan Damopolii, M. (2014) Action Research: Teori, Model, dan Aplikasi. Jakarta: Kencana. 